\title{
ORIGINAL ARTICLE \\ First record of dawn bat Eonycteris spelaea (Dobson, 1871) (Mammalia: Chiroptera: Pteropodidae) from western Nepal
}

\author{
Basant Sharma ${ }^{1 *}, 2,3$, Sanjeev Baniya ${ }^{1,2,3}$, Anoj Subedi ${ }^{3}$, Kritagya Gyawali ${ }^{1,3}$, Shristee Panthee ${ }^{1,3}$, \\ Prashant Ghimire ${ }^{3}$, Bhuwan Singh Bist ${ }^{3}$, Milan Budha ${ }^{3}$
}

\author{
${ }^{1}$ Bat Friends Pokhara, Nepal \\ ${ }^{2}$ Nepal Bat Research and \\ Conservation Union (NeBRCU), \\ Nepal \\ ${ }^{3}$ Tribhuvan University, Institute \\ of Forestry (IoF), Pokhara, Nepal \\ *Corresponding author email: \\ b.s.sharma237@gmail.com
}

\begin{abstract}
This short note aims to document the first record of dawn bat Eonycteris spelaea from western Nepal. A single specimen was captured with a ground level mist net within Banpale forest of the Institute of Forestry (IoF) Pokhara on 1st April 2018. A total of five fruit bat species are now known to occur in Nepal, three of which within western Nepal. This paper presents the fourth record of E. spelaea for Nepal which is first documented occurrence for the Pokhara valley and western Nepal.
\end{abstract}

DOI: https://doi.org/10.14709/BarbJ.11.1.2018.11

Keywords: Banpale forest, Eonycteris spelaea, Fruits bats, Institute of Forestry (IoF), Pokhara

received: April, 24th 2018

accepted: November, 27th 2018

\section{INTRODUCTION}

Old world fruits bats are members of the family Pteropodidae which is composed of 42 genera and around 182 species globally (Simmons 2005, Wilson \& Mittermeier 2009), 13 of which occur around the Indian subcontinent (Srinivasulu et al. 2010). Five species of Pteropodids are known to occur in Nepal, four of which are relatively widespread: Eonycteris spelaea, Pteropus giganteus (Brünnich, 1782), Rousettus leschenaultii (Desmarest, 1820) and Cynopterus sphinx (Vahl, 1797). There is no definitive record of Sphaerias blanfordi (Thomas, 1891) however it is suggested to occur in eastern of Nepal (Leekagul \& McNeely 1977, Acharya et al. 2010). Of these five, three species have been previously recorded in western Nepal and in Pokhara valley: $R$. leschenaultii, P. giganteus and C. sphinx (Acharya et al. 2010).

E. spelaea was initially only known from Myanmar, Thailand, Laos, Vietnam, Cambodia, Malaysia, Indonesia, Philippines (Blanford 1891, Ellerman \& Morrison-Scott 1951) and India (Bates \& Harrison 1997). In Nepal, this species was recorded for the first time in 2000 from the vicinity of Nepal Conservation Research and Training Centre Sauraha, Chitwan, at an elevation of $200 \mathrm{~m}$ a.s.l. and at Dhangari Khola, Tiger Tops (33km west of Sauraha) (Myers et al. 2000). Following this, the species was recorded at two caves (Bhairav and Main cave) located within the Khotang district by Thapa (2012), at an elevation of $1373 \mathrm{~m}$ a.s.l. This was the first colony record of E. spelaea in Nepal and the second species distribution record for the country. Lastly, it was recorded from Shaktikhor, Chitwan by Acharya et al. (2015) whilst identifying the bat species hunted by the Chepang community (traditional bat hunters of Nepal). Subsequently, there have been no more documented sightings of the species in Nepal. It is listed as Least Concern in IUCN Red List (Francis et al. 2008) however, due to the limited records of E. spelaea in Nepal, and thus a limited understanding of its national population, it is categorized as Data Deficient within the National Red List (Jnawali et al. 2011). Here we report the presence of $E$. spelaea for the first time in Pokhara, Kaski. This is the only known species of the genus Eonycteris recorded in Nepal (Acharya et al. 2010) or elsewhere within Southern Asia (Nameer et al. 2016, Srinivasulu et al. 2010).

\section{METHODS}

The study was conducted at the Banpale forest of Tribhuvan University, Institute of Forestry (IoF) Pokhara (located in Hariyokharka, Pokhara, Kaski district, Nepal). This study was part of a training program (Bat Capturing, Handling and Identification) undertaken by the members of Bat Friends Pokhara under the project "Bats Survey and Conservation Outreach Programs along Kaligandaki Canyon of Nepal" funded by Rufford Foundation, UK in 2017. The total extent of the institute is 50ha; of which 30 ha is forested. The forest is unlogged (however firewood collection is prominent) and largely dominated by Castanopsis indica (Roxb. ex Lindl.) A.DC., Schima wallichii Choisy, Bombax ceiba L., Dalbergia sissoo DC., Michelia champaca L., Diploknema butyracea (Roxb.) H.J.Lam and Dendrocalamus sp.

Two sizes of mist net (height $2.6 \mathrm{~m}$, length $4 \mathrm{~m}$ and $6 \mathrm{~m}$, and $38 \mathrm{~mm}$ mesh) were deployed to capture the bats 
$>50 \mathrm{~cm}$ from ground level across the forest trail near $(50 \mathrm{~m}$ from) Diploknema butyracea trees. Mist nets were left open from 6:00 PM to 9:00 PM and continuously checked at an interval of 10 minutes to reduce severe entanglement of captured bats. External morphometric measurements were taken using a vernier caliper $(0.01 \mathrm{~mm}$ accuracy). The measurements taken include the head and body length $(H B)$, forearm length (FA), ear length (EL), tail length ( $T L)$, hind foot length (HF), wingspan (WSP), tibia length (TIB), 3rd meta tarsal and phalanges length ( $3 \mathrm{mt}, 1 \mathrm{ph} 3 \mathrm{mt}, 2 \mathrm{ph} 3 \mathrm{mt})$, 4 th meta tarsal and phalanges length $(4 \mathrm{mt}, 1 \mathrm{ph} 4 \mathrm{mt}$, $2 \mathrm{ph} 4 \mathrm{mt})$ and 5 th meta tarsal and phalanges length $(5 \mathrm{mt}$, $1 \mathrm{ph} 5 \mathrm{mt}, 2 \mathrm{ph} 5 \mathrm{mt})$. The body weight (BW) was measured using a pesola spring balance (1gm accuracy). The species was identified using "Bats of Nepal: A field guide book" (Acharya et al. 2010) and Bates \& Harrison (1997).

\section{RESULTS}

A single sub-adult male $E$. spelaea was caught in Banpale forest of loF Pokhara $\left(28^{\circ} 11^{\prime} 15.2^{\prime \prime} \mathrm{N}, 83^{\circ} 59^{\prime} 26.9^{\prime \prime} \mathrm{E}\right)$ at an elevation of $798 \mathrm{~m}$ a.s.I. on 1st April 2018 at 7:45 PM (2 hours after sunset) in full moon light. The morphometric measurements are provided in Table 1 and the updated distribution map of E. spelaea is provided in Fig. 1.

The specimen was released at the point of capture and no genetic analysis was conducted. We identified the species using the following morphological characteristics; 1) the absence of claw on 2nd digit, 2) muzzle length, 3) tail length and 4) the presence of the anal glands. E. spelaea is a medium-sized fruit bat resembling Rousettus sp. but differs characteristically by the absence of a claw on second digit,

Table1. The morphometric measurements of E. spelaea from Banpale forest of loF Pokhara, Kaski, Nepal.

\begin{tabular}{lcc}
\hline Parameters & Measurements $(\mathrm{mm})$ & Acharya et al. 2010 \\
\hline FA & 71.3 & $66.0-78.0$ \\
HB & 99.5 & $92.0-130.0$ \\
TL & 10.6 & $10.5-23.0$ \\
HF & 17.9 & $17.0-21.0$ \\
EL & 19.9 & 16.9-21.0 (Bates and \\
WSP & 379.6 & Harrison 1997) \\
TIB & 29.5 & Not available \\
$3 \mathrm{mt}$ & 42.7 & Not available \\
1ph3mt & 32.1 & Not available \\
2ph3mt & 44.7 & Not available \\
$4 \mathrm{mt}$ & 44.7 & Not available \\
1ph4mt & 22.4 & Not available \\
$2 \mathrm{ph} 4 \mathrm{mt}$ & 26.7 & Not available \\
$5 \mathrm{mt}$ & 41.5 & Not available \\
$1 \mathrm{ph} 5 \mathrm{mt}$ & 21.4 & Not available \\
$2 \mathrm{ph} 5 \mathrm{mt}$ & 18.7 & Not available \\
BW (gm) & 68 & Not available \\
\hline
\end{tabular}



Fig. 1 - Updated distribution map of dawn bat Eonycteris spelaea from Nepal. // Source: Bajracharya (2013), Map of Nepal 2010: IClMOD, created using Arc GIS 10.3.1

which was confirmed for this specimen and subsequently verified before its release. The muzzle was also comparatively elongated as in R. leschenaultii (Fig. 2). The tail was short (but longer than $R$. leschenaultii or $C$. sphinx) and its tip protruded from the interfemoral membrane (Fig. 2). Large, kidney-shaped glands were present on either side of the anal opening (Fig. 2). The pelage was short, velvety and flat to the skin, colored dorsally dark-brown and ventrally mottled grey-brown. The muzzle and the tibia were naked. The wing membranes were uniformly dark brown and underside of the forearm was moderately hairy (Bates \& Harrison 1997).
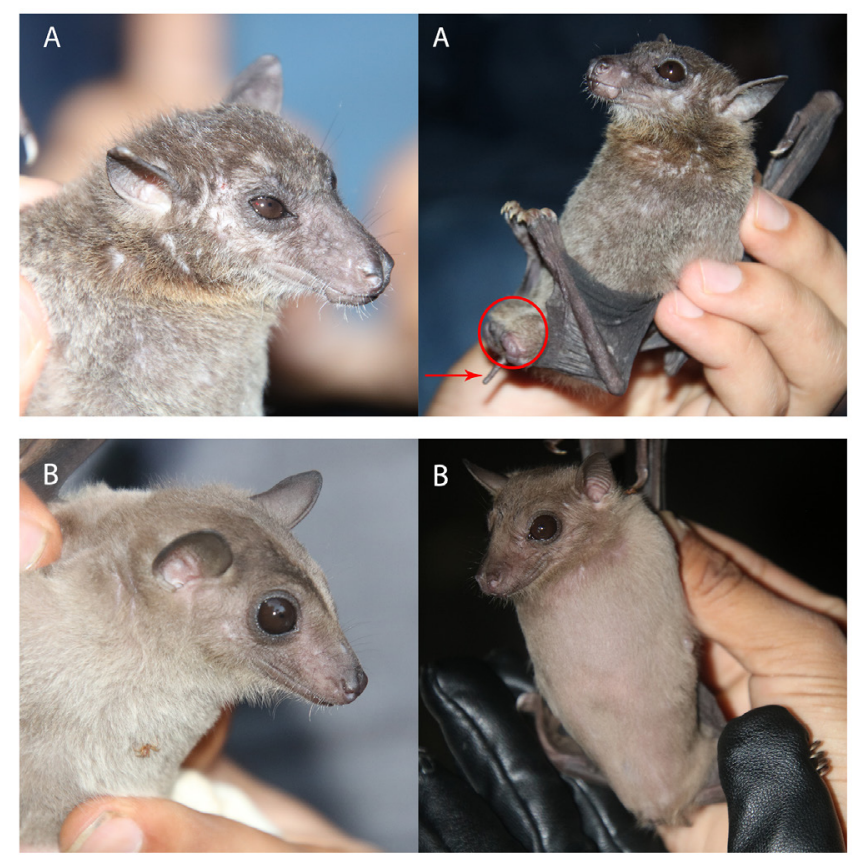

Fig. 2 - Dawn bat Eonycteris spelaea (A) captured from Banpale forest of Institute of Forestry (IoF) Pokhara, Kaski, Nepal with Rousettus leschenaultii (B) captured from Ranipauwa, Myagdi, Nepal during the project under Rufford Roundation, UK. Kidney shaped anal glands (red circle) and tail (red arrow) // Picture credits: E. spelaea by Basant Sharma and $R$. leschenaultii by Anoj Subedi. 


\section{DISCUSSION}

The present finding of this species from Banpale forest is the western most record of E. spelaea from Nepal, representing the fourth report in the literature for the country (Myers et al. 2000, Thapa 2012, Acharya et al. 2015). With this note we confirm that E. spelaea is present within 3 of the 77 districts of Nepal; Chitwan (Myers et al. 2000, Acharya et al. 2015), Khotang (Thapa 2012) and Kaski (Fig. 1). This record infers that either the species has previously been overlooked or that it has extended its range. This supports the hope of finding this species further west in Nepal.

E. spelaea is a nectarivore and feeds on the nectar of Diploknema butyracea, Oroxylum indicum (L.) Kurz and Musa sp. (Acharya et al. 2010, Acharya et al. 2015), each of which is available at the site. The flower of $O$. indicum blooms during rainy season (May-August) (Kirtikar \& Basu 2001), D. butyracea during winter season (January-March) (Dhakal 2014) and Musa spp. in all year round and their flowers produce sugary nectar. The bat was captured in April, during which month most of the flowers of $D$. butyracea were observed to have fallen to the ground (few remaining in tree branches), producing immature fruits in tree branches (fruits mature during June/July). This indicates $E$. spelaea might use loF premises as foraging ground during the flowering season of $D$. butyracea. However, whether these bats feed during the flowering season of other plant species, as well as their food resource preferences, remains unknown and requires further study. Further research would also be needed to identify where this species is roosting.

Currently, all species of fruit bat found in the Pokhara valley have been recorded inside the loF, Pokhara (Acharya et al. 2010). This site provides an abundance of food resources for fruit bats, such as Diploknema butyracea, Elaeocarpus ganitrus Roxb. ex G.Don, Psidium guajava L., Carica papaya L. and Litchi chinensis Sonn. These and other available tree species collectively may provide sufficient food resources for these bats which might be the reason for all fruit bat records, excluding Sphaerias blanfordi.

Pokhara valley also harbors plenty of food resources for E. spelaea. D. butyracea is scattered throughout parks such as Shanti Banbatika, premises of Prithivi Narayan Campus, government places including green pasture in Hariyokharka, public places along roadsides and several private home gardens. This indicates these areas may also provide suitable foraging habitat for E. spelaea. E. spelaea is cave dweller and known to travel long distances to forage (Acharya et al. 2015). Since the area contains numerous caves, Pokhara valley may provide roosting sites for $E$. spelaea. As of yet, most of these caves have not been surveyed for bats. To increase our understanding of this species' distribution and activity in Pokhara Valley, bat surveys within unexplored caves, at potential foraging sites and a more detailed study on the distribution of food resources is strongly recommended. With the first record of E. spelaea in Pokhara valley, this note now opens up new opportunities for further research to assess their abundance, and foraging behavior in this area. It also promotes further work to understand the key roles of fruit bats within this mosaic urban habitat and to alert the Pokhara valley to their additional responsibility for this species conservation.

\section{ACKNOWLEDGEMENTS}

We are grateful to Dr. Pushpa Raj Acharya, Chairperson of Nepal Bat Research and Conservation Union (NeBRCU) for confirmation of species identification and Sanjan Thapa, researcher of Small Mammal Conservation and Research Foundation (SMCRF) for providing distribution locations from Khotang district. We are thankful to Rufford Foundation UK for proving grant support to the project. We would like to express our sincere thanks to former campus chief of Institute of Forestry (IoF) Pokhara, Dr. Bir Bahadur Khanal Chhetrri and wildlife department of the institute for providing permission to carry out bat trapping. We would also thank anonymous reviewers for their comments, which have greatly improved our short note and to Adrià López-Baucells for his continuous invaluable suggestions and guidance for this publication. We are thankful to members of Bat Friends Pokhara and Nepal Bat Research and Conservation Union (NeBRCU) for their voluntary contribution during the field observations.

\section{REFERENCES}

ACHARYA, P.R. (2016). Conservation Initiatives for Fruit Bats in Nepal. Final report. Rufford Foundation UK, 6 pp.

ACHARYA, P.R., ADHIKARI, H., DAHAL, S., THAPA, A. \& THAPA, S. (2010). Bats of Nepal-a field guide. ed: Small Mammals Conservation and Research Foundation, Nepal, 114 pp.

ACHARYA, P. R., RACEY, P.A., MCNEIL, D., SOTHIBANDHU, S. \& BUMRUNGSRI, S. (2015). Timing of cave emergence and return in the dawn bat (Eonycteris spelaea, Chiroptera: Pteropodidae) in Southern Thailand. Mammal Study, 40(1): 47-52. https://doi.org/10.3106/041.040.0108

BATES, P.J.J. \& HARRISON, D.L. (1997). Bats of the Indian sub-continent. ed: Harrison Zoological Museum, London, United Kingdom, 258 pp.

BLANFORD, W.T. (1891). The Fauna of British India, including Ceylon and Burma. Mammalia. ed: Taylor \& Francis. London, United Kingdom, 617 pp.

DHAKAL. B.D. (2014). Development of Chyuri (Diploknema butyracea Roxb) Fruit Biomass Models (A case study from Piple Basaha Community Forest of Baglung, Nepal). Institute of Forestry (IoF), Tribhuvan University, Pokhara, Nepal.

ELLERMAN, J.R. \& MORRISON-SCOT,T T.C.S.T. (1951). Checklist of Palaearctic and Indian Mammals 1758 to 1946. British Museum (Natural History), London, United Kingdom, 810 pp.

FRANCIS, C., ROSELL-AMBAL, G., TABARANZA, B., CARINO, P., HELGEN, K., MOLUR, S. \& SRINIVASULU, C. (2008). Eonycteris spelaea. The IUCN Red List of Threatened Species 2008: e.T7787A12850087. http:// dx. doi . org/10.2305/IUCN.UK.2008. RLTS. T7787A12850087.en. Downloaded on 11 July 2018 
JNAWALI, S.R., BARAL, H.S., LEE, S., SUBEDI, N., ACHARYA, K.P., UPADHAYAY, G.P., PANDEY, M., SHRESTHA, R., JOSHI, D., LAMICHANE, B.R., GRIFFITHS, J., KHATIWODA, A. \& AMIN, R. (2011). Pteropus giganteus. In: The Status of Nepal's Mammals: The National Red List Series. ed.: Department of National Parks and Wildlife Conservation (DNPWC), Kathmandu, Nepal, 214 pp.

KIRTIKAR, K.R. \& BASU, B.D. (2001). Indian Medicinal Plants. Oriental Enterprises, Dehradun, 4: 1105-1107.

LEKAGUL, B. \& MCNEELY, J.A. (1977). Mammals of Thailand. ed: Association for the Conservation of Wildlife, Bangkok, Thailand, 758pp.

NAMEER, P.O., ASHMI, R., ARAVIND, S.K. \& SREEHARI, R. (2016). First record of Dobson's Long-tongued Fruit Bat Eonycteris spelaea (Dobson, 1871) (Mammalia: Chiroptera: Pteropodidae) from Kerala, India. Journal of Threatened Taxa, 8(11): 9371-9374. https://doi. org/10.11609/jott.2496.8.11.9371-9374

MYERS, P., SMITH, J.D., LAMA, H., LAMA, B. \& KOOPMAN, K.F. (2000). A recent collection of bats from Nepal, with notes on Eptesicus dimissus. Zeit-schrift für Saugeteirkunde. International Journal of Mammalian Biology, 65(3): 149-156.
SIMMONS, N.B. (2005). Order Chiroptera, pp. 312-365. In: Wilson, D.E. \& D.M. Reeder (eds.). Mammal Species of the World: A Taxonomic and Geographic Reference (3rd Edition). ed: The Johns Hopkins University Press, Baltimore, USA, 743pp.

SRINIVASULU, C., RACEY, P.A. \& MISTRY, S. (2010). A key to the bats (Mammalia: Chiroptera) of South Asia. Journal of Threatened Taxa, 2(7): 1001-1076. https://doi. org/10.11609/JoTT.02352.1001-76

THAPA, S. (2012). Altitudinal Variation in Bats, Understanding People's Perception to Bats and Creating Bat Conservation Awareness in Sagarmatha (Everest) Zone, Eastern Nepal, 5 pp.

WILSON, D.E. \& MITTERMEIER, R.A. (2009). Handbook of the Mammals of the World. ed: Lynx Edicions Barcelona,, Barcelona, Spain, 727pp. 